\title{
The Role of Government Expenditure and Investment for MSME Growth: Empirical Study in Indonesia
}

\author{
P. Eko PRASETYO ${ }^{1}$
}

Received: April 27, 2020 Revised: August 23, 2020 Accepted: August 28, 2020

\begin{abstract}
In Indonesia, micro-, small- and medium-sized enterprises (MSMEs) are introduced to increase income by providing many easier jobs to improve economic growth. They have also been reported to be generally supportive of the local industry. The government policies on investment and expenditure have the ability to promote MSMEs and economic growth. Therefore, this research was conducted to analyze the theoretical background and empirical study to investigate government's role to promote MSMEs growth in Indonesia. The secondary data after the 2008 global financial crisis recorded quarterly from 2009 to 2019 Q3 were analyzed using the Ordinary Least Square (OLS) regression model. The results showed government expenditure has a positive and significant contribution to small- and medium-sized enterprises, but the effect was not significant for micro-businesses. Meanwhile, the investment sector was discovered to have a positive and significant effect on MSMEs. The policy implications of the Indonesian government are expected to focus on its expenditure's role as the most important factor for "social-economic protection of the community" through micro-enterprises, which are numerous and more attached to the real community economic-social life. Therefore, the existence of micro-businesses is very helpful for the lower classes despite their high vulnerability to crisis.
\end{abstract}

Keywords: Government Expenditure, Investment, Economics, MSME growth, Indonesia

JEL Classification Code: H53, H54, R42

\section{Introduction}

The impact of the Covid-19 pandemic is multidimensional - psychologically, materially and recessionary, so that, in this status of "new normal", additional government spending is needed to overcome these challenges. Theoretically and empirically, increased government spending is often used to restore economic growth due to the crisis, and economically and politically its use must also be efficient and effective. Therefore, hard and smart work is needed with the status of "new norms" so that government expenditure policies

${ }^{1}$ First Author and Corresponding Author. Lecturer, Department of Development Economics, Faculty of Economics, Universitas Negeri Semarang, Indonesia [Postal Address: Building L2, Campus UNNES Sekaran Semarang, Indonesia]

Email: pekoprasetyo@mail.unnes.ac.id

(c) Copyright: The Author(s)

This is an Open Access article distributed under the terms of the Creative Commons Attribution Non-Commercial License (https://creativecommons.org/licenses/by-nc/4.0/) which permits unrestricted non-commercial use, distribution, and reproduction in any medium, provided the original work is properly cited. remain optimal, efficient and effective and able to carry out economic recovery well. At this time, a policy program to strengthen the quality of the institutional structure and social security and economic culture of the community through MSMEs and social entrepreneurship is urgently needed to become one of the on-track efforts in the status of "new normal" (Prasetyo et al., 2020c; 2020d; ASEAN, 2020). Because the existence of the MSME sector is able to become a supply chain of social investment and an important driver: equality, employment opportunities, sustainable economic growth, and poverty reduction, (Prasetyo, 2008; Prasetyo \& Dzaki, 2020e; Tambunan, 2019).

In Indonesia, micro-, small- and medium-sized enterprises (MSMEs) are introduced to increase income by providing many easier jobs to improve economic growth. They have also been reported to be generally supporting the local industry (Srinivas, 2013; Mujahid, \& Begam, 2019). Moreover, the economic growth of developed countries such as Japan, Korea, Taiwan, and several others was significantly generated by SMEs activities (Katua, 2014). However, several MSMEs in developing countries like Indonesia are facing severe challenges and weaknesses requiring 
immediate and serious government attention through subsidies and regulations. These include the implementation of policies to promote local MSMEs development in order to alleviate poverty, unemployment, inequality, and also to increase income and economic growth (Prasetyo, 2008; Prasetyo et al., 2020c, 2020d; Asghar et al., 2011).

The role and function of government expenditure in economic growth and other sectors have been a subject of debate from the time of Adam Smith to the present. Combined with investment, it is inherent in all sectors ranging from regional to national levels. The effects of these two concepts on economic growth have been researched by several scholars (Frank et al., 2014; Gisore et al., 2014; Hasnul, 2015; Nurlina, 2015; Meyer \& Muzindutsi, 2017; Oladele et al., 2017; Mazorodze, 2018; Nguyen, 2019). However, different results and ambiguous conclusions have been reported, even for the industrial sector. This has, therefore, led to further debate (Thanh, \& Nguyen, 2019) with one of the most controversial literature problems being the direction of the causal relationship between public expenditure and economic growth (Karahan \& Colak, 2019). According to Kuncoro (2014), not all government expenditures are productive and this statement strengthens this paper's urgency to contribute both theoretically and empirically to this discourse. Its novelty was to comprehensively explain government expenditure and investment's influence on MSME growth, which is expected to stimulate economic growth.

The most recent evidence showed the MSMEs in Indonesia are largely dominated by micro- and small-sized enterprises (MSEs) mostly due to the prevalence of poverty (Tambunan, 2019). However, MSMEs growth in several countries has been observed to be very dilemmatic requiring the intervention of conducive government expenditure and investment policies. This is necessary considering the importance of these businesses in stimulating entrepreneurial climate, increasing income, creating employment, alleviating poverty, contributing to GDP, and ultimately driving economic growth (Prasetyo \& Kistanti, 2020a; Prasetyo, 2008; Tambunan, 2019; Weldeslassie et al., 2019). They, however, face several quite heavy constraints and challenges such as lack of credit, weak market relations, inadequate training, dependency, weak human resource development, and low productivity (Tambunan, 2019; Weldeslassie et al., 2019). These led to Tambunan's (2019) recommendation that government policies need to provide direct facility assistance at production sites and alternative funding facilities with low-interest rates and requirements.

Based on this background, this paper's novelty and urgency were to further examine and explain the contribution of government expenditure and investment in promoting MSMEs growth in Indonesia. The specific purpose was to investigate and explain the main factors affecting this growth, while the novelty and originality involved the assumption that economic growth has a greater role to play and not vice versa. Furthermore, more focus was placed on investigating the contribution of government expenditure and investment towards each sector through the novelty specification model. The results are expected to further prove the findings of previous research that MSMEs and other small industries in Indonesia grow and develop because of their creativity while large businesses or industries leverage on more facilities and credit provided by the State.

In the status of "new normal", favoring only large businesses is no longer appropriate. This partisanship policy model will not solve the real-life problems of community welfare and will continue to increase inequality. Even though large businesses and MSMEs are the same as crisis mitigation, their main function is still different. The main function of large businesses is more to guarantee the growth of output. Meanwhile, the main function of UMKM is more on social safety networks and job opportunity providers. Therefore, government expenditure policies must be optimized for both large businesses and MSMEs. However, in the status of "new normal", additional government spending should be more focused on the socio-cultural economic assistance of the community first. The specific purpose of this paper is to explain the argument for the importance of focusing on the policy choices.

\section{Literature Review}

In macroeconomic theory, government expenditure is integral to the fiscal policy instruments usually used to increase income and economic growth through consumption and investment. There are several economic theorists associated with this concept, but those related to this research include Adolf Wagner (1835-1917) or better known as Wagner's law (1893), A.C. Pigou (1928), Peacock and Wiseman's (1961) theory, William G. Bowen (1965), the theory of developing government expenditure from Musgrave as well as the NeoClassical and Keynesian economists. Furthermore, specific literature studies used are based on Wagner's law, which states that economic performance has a fundamentally positive impact on public sector growth.

This law shows there is a functional relationship between government expenditure and economic growth. It also states that government expenditure initially tended to increase at a faster rate and, subsequently, steadily due to an increase in the income growth and argument and this was associated with the need for industrialization performance and economic development. Even though there are several criticisms while the theory was being developed, the most important thing in relation to this research is the positive impact on the public sector and the basis of its arguments. This is due to the fact that government expenditure functions not to increase only 
economic growth but also industrial growth such as MSMEs and economic development.

Wagner's theory shows an increase in a country's real per-capita income during the industrialization process usually leads to an increment in total public expenditure. This, therefore, theoretically assumes the emergence of the MSME industry and entrepreneurship in Indonesia in this modern era is able to increase political pressure and advance socio-economic community to achieve mutual prosperity according to the fifth Pancasila precepts (the official Indonesia foundational philosophical theory of Indonesia). It also means any increase in government expenditure should be able to promote MSMEs growth which are functioning as the means to cushion the effects of the 1998 and 2008 economic crises by reducing poverty and providing new jobs (Prasetyo, 2008). However, considering the crisis as a public disturbance problem means it can be supported by the Peacock-Wiseman's basic theory which states that the public expects the government or State to have the ability to immediately overcome a crisis by adjusting its expenditure with new socio-economic ideas. This means government inability to make proper and correct adjustments may create a problem of trust from the community.

Wagner's Law is seen as the first public expenditure theory model in the public finance history, while Wagner and Peacock-Wiseman's theory is established on the basics due to the existence of several ambiguous conclusions from several researchers. Moreover, several studies on the impact of government expenditure on economic growth have shown different results, thereby, creating opportunity for further research. Thanh and Nguyen (2019) investigated the dynamics of government expenditure and economic growth in China using productivity growth in human capital as the indicator by applying Markov estimates to annual time series data over 1952-2014. An imbalanced relationship was found between the variables. The research confirmed the level of government expenditure's inability to increase productivity growth in human capital. Meanwhile, Nyasha's and Odhiambo, (2019) research supported the statement that economic growth is influenced by government expenditure without any increase in causal relationship.

Another empirical research also explained government expenditure in Nigeria increased economic growth, even though the impact was very small and less than one percent (Akpan and Abang, 2013). Government expenditure and GRDP have also been reported to have a long-term equilibrium relationship with positive and strong correlations (Kasimu and Aggreh, 2014). Moreover, Frank et al., (2014) found government expenditure to have a significant positive impact on economic growth in the long run but a negative impact in the short term based on the research conducted in Ghana. Hasnul (2015) showed a negative correlation between the variables in Malaysia over the past 45 years, while a positive and significant effect was recorded from 2004 to 2013 in Indonesia by Nurlina (2015) based on GDP. Furthermore, Uzuner et al., (2017) found a positive and significant influence, while the empirical research conducted by Ebaid and Bahari (2019) in Kuwait supported the directional causality from government expenditure to economic growth, only when real government expenditure per capita is the proxy for state activity and real GDP per capita is the measure for economic growth. The effect was also observed to have varied for each sector and this was observed to be an interesting topic for future research.

The literature reviewed on the role of government expenditure and investment on economic growth did not provide the same conclusion. According to Meyer and Muzindutsi, (2017), investment had a positive and significant effect in the short and long term, while government expenditure only had a small and insignificant effect in South Africa. The empirical research by Nguyen (2019) showed Vietnam's state budget expenditure had a positive effect on the economy, but each major component had a different impact with the recurrent expenditure observed to have a significant positive impact while no strong evidence was discovered to confirm the relationship between the statistically insignificant development investment and economic growth. Furthermore, Mose et al., 2014) specifically confirmed investment expenditure relatively encourages economic growth, while consumption impedes it, and human capital expenditure was found to be insignificant. Meanwhile, Butkiewicz and Yanikkaya, (2011) reported government consumption expenditure in developing countries to be ineffective with the ability to cause harm and has negative effects on their economic growth.

The urgency of this research is based more on Wagner and Peacock-Wiseman's theory as well as Ebaid and Bahari's (2019) recommendations, while the novelty and originality are more specific, especially with the main focus on the contribution of government expenditure and investment to the growth of MSME entrepreneurship instead of the economic growth. However, there are only a few recent literature reviews found on this issue with the results showing the SME sector has been widely accepted as an engine of economic growth and poverty alleviation in the world (Katua, 2014). Moreover, developed countries have shown the MSME sector to be the basic link for their public economic growth and development. It is, however, important to note that policymakers in the field of entrepreneurship and MSME are generally complicated and messy (Asghar et al., 2011). Essien et al., (2016) showed causality was in line with the output and productivity of SMEs for public expenditure while Cephas et al., (2018) found no significant relationship between tax rate (TAR) and the growth of SMEs, but a significant effect was observed for government expenditure (GEXP) in Nigeria. Furthermore, a recent research review 
by Metasari (2019) using panel data of 2013-2015 showed public services and education projected by gross participation data to have a positive influence on the MSE development, while economic growth and minimum wage policies have a negative influence in Indonesia.

\section{Methodology}

The broad outline of the research method was classified into two and these involve data and method and empirical model to ensure easy understanding, relevance, and simplicity.

\subsection{Data and Method}

The main sources of data and variables used were quarterly economic data recorded after the 2008 global economic crisis covering the 2009-2019 Q3 period with the dimension on all variables used as a unit to measure the growth. The main subjects were MSME sector businesses instead of SMEs used in previous studies (Cephas et al., 2018; Metasari, 2019). In line with the recommendations from previous researchers, the method used was comprehensively detailed with the use of four different specification models including (1) general MSME growth as well as (2) micro, (3) small, and (4) medium business sectors, which are considered as empirical novelty models in this research.

The stages of research activities were conducted rigorously, thoroughly, and carefully. In the initial stages, the classical assumption test was conducted on each experimental model choices before the empirical analysis model selection and application after which a MSME model general form was selected. This was followed by considering three subsequent models as the best rescue due to the specification bias in the general one. Scientifically, the experimental model was tested to determine different independent factors considered important to MSMEs growth. The final step involved the model selection based on the subject matter and research objectives after it had passed the classical assumption test and scientifically confirmed to be the best.

\subsection{Empirical Model}

The general purpose of this empirical model was to evaluate the impact of government expenditure, GDP, investment, and working capital on MSME growth in Indonesia. Moreover, in line with several scientific arguments, the specific purpose of the empirical specification model was to further examine government expenditure and investment effects on MSMEs. The technique used includes the Ordinary Least Square (OLS) linear regression analysis model, which technically involved using the EViews 10 . Meanwhile, the main important variables included in the empirical analysis model have been previously explained above. In order to make the research activity process easier to understand, the systematics of the four models of linear regression analysis equations using the OLS method is presented as follows.

$$
\begin{aligned}
\text { MSMEs }= & \tau_{0}+\tau_{1} \operatorname{LogGE}+\tau_{2} \operatorname{LogPDB}+ \\
& \tau_{3} \operatorname{LogIN}+\tau_{4} \log \mathrm{WC}+\varepsilon_{1} . \\
\mathrm{MiB}= & \alpha_{0}+\alpha_{1} \operatorname{LogGE}+\alpha_{2} \operatorname{LogPDB}+\alpha_{3} \mathrm{IN}+ \\
& \alpha_{4} \mathrm{WC}+\alpha_{5} \mathrm{SmB}+\alpha_{6} \mathrm{MeB}+\varepsilon_{2} . \\
\mathrm{SmB}= & \beta_{0}+\beta_{1} \operatorname{LogGE}+\beta_{2} \operatorname{LogPDB}+\beta_{3} \mathrm{IN}+ \\
& \beta_{4} \mathrm{WC}+\beta_{5} \mathrm{MiB}+\beta_{6} \mathrm{MeB}+\varepsilon_{3} . \\
\mathrm{MeB}= & \partial_{0}+\partial_{1} \operatorname{LogGE}+\partial_{2} \operatorname{LogPDB}+\partial_{3} \mathrm{IN}+ \\
& \partial_{4} \mathrm{WC}+\partial_{5} \mathrm{MiB}+\partial_{6} \mathrm{SmB}+\varepsilon_{4} .
\end{aligned}
$$

Where: MSMEs are the level of growth in question, $\mathrm{MiB}$ is the micro-business level variable, $\mathrm{SmB}$ is small business level, and $\mathrm{MeB}$ is the medium business level variable subsequently considered as the dependent variable. Furthermore, the independent variables include the GE (level of government expenditure), GDP (level of economic growth), IN (level of public investment), and WC (level of working capital). Meanwhile, $(\tau, \alpha, \beta$, and $\partial$ ) is the desired parameter value of the linear regression coefficient while the quantity $\varepsilon_{-} n$ is a random residue in each equation model.

Basically, defining the variable concept as endogenous and exogenous, considering the three specification models in one analysis group, and conducting order and rank tests as necessary and sufficient conditions leads to the consideration of the model as an equation model simultaneous system. However, it was impossible to implement this step at this research stage and in practice. Therefore, the specification model was considered an ordinary OLS linear regression model in line with the level of urgency, novelty, and subject matter originality and research objectives examined.

\section{Empirical Results and Discussion}

Methodologically, the results shown in Table 1 are the general model used as the introduction to explain and compare empirical evidence from the scientific process to strengthen the argumentation in selecting the results of the specification model. However, due to the results imperfection, it is not recommended to be discussed and interpreted further.

Further discussion tended to use more results in the empirical form of model 2, model 3, and model 4 
Table 1: Results of the MSME General Empirical Regression Model

\begin{tabular}{|l|c|c|c|c|}
\hline Variable & Coefficient & Std. Error & t-Statistic & Prob. \\
\hline C & 9315928. & 4981731. & 1.870018 & 0.0690 \\
\hline Log (GE) & 103290.9 & 53884.22 & 1.916904 & 0.0626 \\
\hline Log (PDB) & -1317121. & 585234.6 & -2.250586 & 0.0301 \\
\hline Log (IN) & 0.072066 & 0.041459 & 1.738232 & 0.0901 \\
\hline Log (WC) & 710421.0 & 267620.0 & 2.654589 & 0.0114 \\
\hline R-squared & 0.446008 & Mean dependent var & 665803.3 \\
\hline Adjusted R-squared & 0.389188 & S.D. dependent var & 147567.7 \\
\hline S.E. of regression & 115330.7 & Akaike info criterion & 26.25564 \\
\hline Sum squared resid & $5.19 E+11$ & Schwarz criterion & 26.45839 \\
\hline Log likelihood & -572.6241 & Hannan-Quinn criter. & 26.33083 \\
\hline F-statistic & 7.849530 & Durbin-Watson stat & 0.525203 \\
\hline Prob(F-statistic) & 0.000097 & & \\
\hline MSME = 9315928 + 103291(LogGE $-317121\left(\right.$ Log PDB) +0.0721 (LogIN) + 710421(LogWC) $+\varepsilon_{1}$ & \\
\hline
\end{tabular}

specifications. Meanwhile, it is possible to use the findings of model 1 presented in Table 1 in a scientific and functional process as a basis for strong arguments and good comparisons. It was observed to have shown a partial significant influence of the role of government expenditure, economic growth, investment, and working capital on MSME growth. However, based on the small R2 value of 44.68 percent and the Durbin-Watson statistical value (DW-test) of 0.525203 , the contribution of all variables was concluded to be small and misleading. It also indicates an auto-correlation case, thereby, declaring model 1 biased requiring correction and with the estimators declared inefficient and misleading. Therefore, there is a need for the model improvement of the model.

Theoretically and empirically, the functional form of model-1 was found to be good and right due to the level of significance, but discovered to have an autocorrelation problem based on the DW value of 0.525203 . This means the OLS form regression model on it was inefficient and the results misleading, but the bias problem was not due to an error in the functional form but the empirical bias in the specification of the variable cases. Moreover, the small R2 value shows the bias was only in the model specification and not an inertia problem. This means, in practice, it is impossible to solve the model-1 rescue evidence by an inertia or lag model, but through the addition of a new variable, which empirically (Das-Solen and Das-Sein) should be present in it. Therefore, three new specification models were successfully developed as the best and correct rescue models and they include model 2, model 3, and model 4. Based on the specification model, the OLS model regression form was declared BLUE (Best, Linear, Unbiased Estimator) and found to be no longer misleading and this made it possible to use the regression results for interpretation.

Table 2 shows the role of government expenditure is partially positively insignificant to the growth of microenterprises in Indonesia, while investment sector factors were partially positively significant during the research period. Furthermore, the economic growth factors measured by the GDP growth as well as the role of small- and mediumsized businesses on the growth of microenterprises was found to be partially negative and significant. This shows the influence of the three factors is certainly not in accordance with the basic economic theory and the proposed empirical model. However, the negative effect on GDP growth could be associated with the impact of the decrease in the GDP level causing the shift from the small, medium, and large businesses to micro ones. Scientifically, researchers are limited to tracking the subsequent impacts because the primary data source has been narrowed to secondary ones. Meanwhile, the role of working capital in model 2 was shown to be negatively insignificant and this was attached to the fact that micro-businesses are generally inefficient at utilizing or managing financial resources from these working capital sources.

The results also showed there is a negative and insignificant influence of working capital on the growth of microbusinesses, therefore, the problem is not in accordance with the expected theoretical basis and empirical model. Due to the use of secondary data, it was difficult for researchers to track the reason for the problem. However, there are indications of additional explanation from previous research 
(Prasetyo, 2019a, 2019b), which showed microbusinesses to generally have very weak productivity and business financial management mainly due to the inability to distinguish between business capital and money for other purposes. This was increasingly observed in areas with many social activities such as celebrations and others. The entrepreneurs use the tactical micro-enterprise funds for interests categorized as very urgent due to the unavailability of other funding options. Moreover, even though they know the money is their working capital, they are often forced to use it first to meet their more pressing needs with the hope of replacing it at a later time, but, in practice, most of the microbusiness actors often have difficulty returning the working capital. In fact, more microbusinesses eventually close down due to the lack of new working capital to develop the business and this shows its vulnerability caused by its ability to grow and die very fast. They generally do not obtain assistance from banks due to the interest rates and complicated rules attached to the process. The banking sector has also been discovered to have any significant contribution to their activities because they are believed not to be profitable due to a large number of administrations. This, therefore, shows strong and firm policies are required to sustain the existence, growth, and development of microbusinesses.

The results of model 3 presented in Table 3 showed government expenditure and investment contributed positively and significantly to the small business sector growth at a 90 percent confidence level. However, economic growth measured by GDP on current prices was found to be negative and insignificant while the role of micro and medium businesses was negative and significant. Meanwhile, working capital was discovered to have a positive and insignificant effect on small businesses. The interesting thing to observe was the improvement in the role of working capital in these small businesses compared to the microbusinesses in model 2. Moreover, a further explanation of the effect of economic growth was difficult due to the lack of enough primary data. Previous studies conducted through the experimental process also showed its impact on micro and small businesses (MSEs) as well as small and medium businesses (SMEs) was negative and insignificant. This means it is the same as the findings of this study presented in Table 1.

The most important critical note is that further examination based on the results in Tables 2, 3, and 4 showed a smaller level of effort to produce less effective financial management as well as the tendency of the role of working capital to be less significant and vice versa. Moreover, working capital was found to be negative and insignificant in micro-businesses, positively insignificant for small ones, and positively significant for those categorized as medium. These results are empirically interesting by recommending efforts should be made to empower business management in micro and small businesses of Indonesia.

Table 2: Results of Empirical Regression Models of Microbusiness

\begin{tabular}{|c|c|c|c|c|}
\hline Variable & Coefficient & Std. Error & t-Statistic & Prob. \\
\hline $\mathrm{C}$ & 114.4283 & 7.197583 & 15.89816 & 0.0000 \\
\hline $\log (\mathrm{GE})$ & 0.194946 & 0.348769 & 0.558954 & 0.5801 \\
\hline Log (PDB) & -1.691349 & 0.596002 & -2.837827 & 0.0078 \\
\hline IN & 0.283513 & 0.086862 & 3.263953 & 0.0026 \\
\hline WC & -0.017883 & 0.038460 & -0.464979 & 0.6451 \\
\hline $\mathrm{SmB}$ & -0.792771 & 0.079095 & -10.02296 & 0.0000 \\
\hline MeB & -1.094275 & 0.122053 & -8.965578 & 0.0000 \\
\hline $\mathrm{UM}_{\mathrm{e}}$ & -1.094275 & 0.122053 & -8.965578 & 0.0000 \\
\hline R-squared & 0.988050 & \multicolumn{2}{|c|}{ Mean dependent var } & 27.84103 \\
\hline Adjusted R-squared & 0.985809 & \multicolumn{2}{|c|}{ S.D. dependent var } & 6.898921 \\
\hline S.E. of regression & 0.821842 & \multicolumn{2}{|c|}{ Akaike info criterion } & 2.606611 \\
\hline Sum squared resid & 21.61357 & \multicolumn{2}{|c|}{ Schwarz criterion } & 2.905199 \\
\hline Log likelihood & -43.82892 & \multicolumn{2}{|c|}{ Hannan-Quinn criter. } & 2.713742 \\
\hline F-statistic & 440.9578 & \multicolumn{2}{|c|}{ Durbin-Watson stat } & 1.782996 \\
\hline Prob(F-statistic) & 0.000000 & & & \\
\hline
\end{tabular}


Table 3: Results of the Empirical Regression Model of Small Businesses

\begin{tabular}{|c|c|c|c|c|}
\hline Variable & Coefficient & Std. Error & t-Statistic & Prob. \\
\hline C & 100.0093 & 15.61196 & 6.405940 & 0.0000 \\
\hline $\log (G E)$ & 0.669430 & 0.366355 & 1.827271 & 0.0770 \\
\hline $\log (P D B)$ & -0.350447 & 0.729859 & -0.480157 & 0.6344 \\
\hline IN & 0.208314 & 0.103826 & 2.006375 & 0.0533 \\
\hline WC & 0.042744 & 0.041713 & 1.024709 & 0.3132 \\
\hline $\mathrm{MiB}$ & -0.956666 & 0.095448 & -10.02296 & 0.0000 \\
\hline MeB & -1.272973 & 0.111773 & -11.38887 & 0.0000 \\
\hline R-squared & 0.953517 & \multicolumn{2}{|c|}{ Mean dependent var } & 31.86923 \\
\hline Adjusted R-squared & 0.944801 & \multicolumn{2}{|c|}{ S.D. dependent var } & 3.842638 \\
\hline S.E. of regression & 0.902806 & \multicolumn{2}{|c|}{ Akaike info criterion } & 2.794532 \\
\hline Sum squared resid & 26.08191 & \multicolumn{2}{|l|}{ Schwarz criterion } & 3.093120 \\
\hline Log likelihood & -47.49337 & \multicolumn{2}{|c|}{ Hannan-Quinn criter. } & 2.901662 \\
\hline F-statistic & 109.4033 & \multicolumn{2}{|c|}{ Durbin-Watson stat } & 2.263875 \\
\hline Prob(F-statistic) & 0.000000 & & & \\
\hline
\end{tabular}

Table 4: Results of the Empirical Regression Model for Medium Businesses

\begin{tabular}{|c|c|c|c|c|}
\hline Variable & Coefficient & Std. Error & t-Statistic & Prob. \\
\hline $\mathrm{C}$ & 75.40640 & 9.882654 & 7.630178 & 0.0000 \\
\hline $\log (\mathrm{GE})$ & 0.496919 & 0.256224 & 1.939389 & 0.0613 \\
\hline $\log (P D B)$ & -0.805735 & 0.495267 & -1.626869 & 0.1136 \\
\hline IN & 0.264966 & 0.061751 & 4.290877 & 0.0002 \\
\hline WC & 0.057742 & 0.028024 & 2.060443 & 0.0476 \\
\hline $\mathrm{MiB}$ & -0.653635 & 0.072905 & -8.965578 & 0.0000 \\
\hline $\mathrm{SmB}$ & -0.630108 & 0.055327 & -11.38887 & 0.0000 \\
\hline R-squared & 0.995253 & \multicolumn{2}{|c|}{ Mean dependent var } & 40.14615 \\
\hline Adjusted R-squared & 0.994362 & \multicolumn{2}{|c|}{ S.D. dependent var } & 8.459527 \\
\hline S.E. of regression & 0.635174 & \multicolumn{2}{|c|}{ Akaike info criterion } & 2.091313 \\
\hline Sum squared resid & 12.91027 & \multicolumn{2}{|c|}{ Schwarz criterion } & 2.389901 \\
\hline Log likelihood & -33.78060 & \multicolumn{2}{|c|}{ Hannan-Quinn criter. } & 2.198443 \\
\hline F-statistic & 1118.079 & \multicolumn{2}{|c|}{ Durbin-Watson stat } & 1.865314 \\
\hline Prob(F-statistic) & 0.000000 & & & \\
\hline
\end{tabular}

The results in Table 4 shows model 4 is the best empirical research model. It was discovered that the contribution of government expenditure, investment, and working capital was partially positive and significant. Meanwhile, the role of micro and small businesses towards medium ones was negative and significant. The role of economic growth measured by the GDP in medium-sized businesses remained negative and insignificant. Furthermore, the $\mathrm{R}^{2}$ value of 
0.995253 showed the role of government expenditure, GDP growth, investment, working capital, micro business, and small businesses contributed 99.53 percent, while the remaining 0.47 percent was influenced by other factors outside model-4. Moreover, the DW values of model 2 , model 3, and model 4 observed to be approaching 2.0 showed the non-existence of auto-correlation and this means the three specification models are good and efficient and not misleading. However, based on the $\mathrm{R}^{2}$ and DW values of 1.865314 , the 4th model was found to be the best.

The negative effect of economic growth for micro-, small- and medium-sized enterprises reinforces the results of previous research that government policies implemented to reduce unemployment, poverty, and income inequality in Indonesia have been a failure (Prasetyo, 2011, 2020). Moreover, the additional increase in government expenditure to assess the Covid-19 virus pandemic impact in the 2020 financial budget needs to be evaluated. Does the government care more about micro- and small-sized businesses than others?

The data used for other variables in this research are very limited, partially available, and incomplete and this means they cannot be scientifically used to study the current Covid-19 pandemic impacts. Therefore, further comprehensive studies are recommended to address the most important function of additional government expenditure on microbusinesses affected by the Covid-19 pandemic, which in real terms affects the community's economic, social and cultural life.

\section{Conclusion}

The causes and effects of the multidimensional global crisis due to Covid-19, make the policy of every country in the world switch to a new economic status called "New Normal". World economic growth and Indonesia are expected to contract, so additional government spending is needed to recover soon. In this phenomenon, government spending must be properly optimized, not only for the recovery of economic growth. However, what is more important is to focus first on the construction of the socio-economic construction of people's lives. The argument is that the main causes and effects of this crisis are different from the previous crisis. The impact of the previous crisis was mainly due to financial problems, so that additional government spending was often focused on economic growth. However, the cause of the multidimensional crisis due to Covid-19 has more impact on the psychology of life, so we need a new policy status called "New Normal", namely, the policy to increase government spending should be further optimized and focused on building the socio-economic construction of people's lives so that they can recover quickly
The results showed a greater level of business leads to better financial management and working capital, consequently, becomes more positive and significant, while a smaller business level causes less efficient financial management, low productivity, and negative, and insignificant working capital. Government expenditures and investments were discovered to be generally positive and significant for MSMEs, but this statement was considered to be misleading due to the fact that government expenditures only contributed positively and significantly to small- and medium-sized enterprises (SMEs), but insignificantly to the growth of micro-businesses. Meanwhile, investment contributed to the MSMEs growth in general. Moreover, the statement that economic growth factors contributed negatively and significant to MSMEs was also found to be misleading because it was found to have a negative and insignificant contribution only to small- and medium-sized enterprises, but significant to micro-businesses using a good specific model.

This research scientifically has limited information from primary data and this made it impossible to have further comprehensive explanations for the relationships. It is, therefore, recommended to conduct another research with more complete and comprehensive primary and secondary data. For example, comprehensive studies are recommended to address the most important function of additional government expenditure on micro-businesses affected by the Covid-19 pandemic, which in real terms affects the Indonesian residents' economic, social, and cultural life. Furthermore, there is a need to pursue policy implications more seriously in the use of government expenditure as the most important function for "economic, social and cultural protection of the community".

\section{References}

Akpan, U. F., \& Abang, D. E. (2013). Does Government Spending Spur Economic Growth? Evidence from Nigeria. Journal of Economics and Sustainable Development, 4(9), 36-53.

ASEAN. (2020). Economic Impact of COVID-19 Outbreak on ASEAN. ASEAN Policy Brief. Jakarta, Indonesia: ASEAN Integration Monitoring Directorate (AIMD) and Community Relations Division (CRD).

Asghar, A. J., Nawaser, K., Paghaleh, M. J., \& Khalsar, S. M. S. (2011). The Role of Government Policy and the Growth of Entrepreneurship in the Micro, Small \& Medium-sized Enterprises in India: An Overview. Australian Journal of Basic and Applied Sciences, 5(6), 1563-157.

Butkiewicz, J. L., \& Yanikkaya, H. (2011). Institutions and the Impact of Government Spending on Growth. Journal of Applied Economics, 14(2), 319-341.

Cephas, G., Sylvanus, U. F., \& Frank, B. I. (2016). Effect of Fiscal Policy on Growth of Small - Medium Scale Enterprises 
In Nigeria. Sahel Analyst: Journal of Management Sciences, 16(4), 122-142.

Ebaid, A., \& Bahari, Z. (2019). The Nexus between Government Expenditure and Economic Growth: Evidence of the Wagner's Law in Kuwait. De Gruyter Review of Middle East Economics and Finance, 28(6), 1-10.

Frank, A., Joseph, O. M., \& Ackah, I. (2014). Government Expenditures and Economic Growth dynamics in Ghana. International Journal of Economics and Empirical Research, 2(5), 180-190.

Essien, J. M., Mepbari, N., Nwikiabeh, L. B. M., \& Piabari, N. (2016). Impact of government spending on small and medium scale businesses in Nigeria. Equatorial Journal of Marketing and Insurance Policy, 1(2),41-56.

Gisore, N., Kiprop, S., Kalio, A., \& Ochieng, J. (2014). Effect of Government Expenditure on Economic Growth in East Africa: A Disaggregated Model. European Journal of Business and Social Sciences, 3(8), 289-304.

Hasnul, A. G. (2015). The effects of government expenditure on economic growth: the case of Malaysia. MPRA Paper No. 71254. Munich Personal RePEc Archive. https://mpra.ub.unimuenchen.de/71254/1/MPRA_paper_71254.pdf

Karahan, O., Colak, O. (2019). Examining the Validity of Wagner's Law versus Keynesian Hypothesis: Evidence from Turkey's Economy. Scientific Annals of Economics and Business, 66(1), 117-130.

Kasimu, A., \& Aggreh, M. (2014). Government Expenditure and Gross Domestic Product: A Test of Wagner's Law on Nigerian Economy. Journal Asian Development Study, 3(3), $1-9$.

Katua, N. T. (2014). The Role of SMEs in Employment Creation and Economic Growth in Selected Countries. International Journal of Education and Research, 2(12), 461-472.

Kuncoro, H. (2014). The economic impacts of government spending cut: The case of Indonesia. Journal of Advanced Research in Law and Economics, 5.2(10), 120-135.

Mazorodze, B. T. (2018). Government Expenditure and Economic Growth in Zimbabwe. African Journal of Business and Economic Research, 13(2), 183-202.

Metasari, K. (2019). Public Service and Micro-Small Enterprise Developments in Indonesia. MPRA Paper No. 91577. Munich Personal RePEc Archive. https://mpra.ub.uni-muenchen. de/91577/1/MPRA_paper_91577.pdf

Meyer, D., \& Muzindutsi, P. F. (2017). The impact of government expenditure and sectoral investment on economic growth in South Africa. Journal of Advanced Research in Law and Economics. 8(6), 1844-1855.

Mose, N., Kalio, A., Kiprop, S., Kibet, L., \& Bagu, J. (2014). Effect Of Government Expenditure On Economic Growth In East Africa: Panel Data Analysis. Journal of International Academic Research for Multidisciplinary, 2(4), 428-444.
Mujahid, N., \& Begam, A. (2019). SMEs Output and GDP Growth: A Dynamic Perspective. Journal of Asian Business Strategy, 9(1), 53-65.

Nguyen, H. H. (2019). The Role of State Budget Expenditure on Economic Growth: Empirical Study in Vietnam. Journal of Asian Finance, Economics and Business, 6(3), 81-89. https:// doi.org/10.13106/jafeb.2019.vol6.no3.81

Nurlina. (2015). The effect of government expenditures on Indonesia economic growth. Journal of Economics, Business, and Accountancy Ventura, 18(1), 1-14.

Nyasha, S., \& Odhiambo, N.M. (2019). The Impact of Public Expenditure on Economic Growth: A Review of International Literature. Folia Oeconomica Stetinensia, 19(2), 81-101

Oladele, M. F., Mah, G., \& Mongale, I. (2017). The Role of Government Spending on Economic Growth in A Developing Country. Risk Governance \& Control: Financial Markets \& Institutions, 7(2), 140-146.

Peacock, A. T., \& Wiseman, J. (1961). The Growth of Government Expenditures in the United Kingdom. Princeton, NJ: Princeton University Press.

Prasetyo, P. E., \& Kistanti, N. R. (2020a). Human capital, institutional economics and entrepreneurship as a driver for quality \& sustainable economic growth. Entrepreneurship and Sustainability Issues, 7(4), 2575-2589.

Prasetyo, P. E. (2020b). Peran Strategis Kewirausahaan dalam Mendukung Kebijakan Four Track Strategy di Indonesia. Jurnal Ekonomi \& Pembangunan (OPTIMUM), 10(1), 84-94.

Prasetyo, P. E., Setyadharma, A., \& Kistanti, N. R. (2020c). The Role of Social Capital in New Products Development and Business Competitiveness Enhancement. International Journal of Scientific \& Technology Research. 9(03), 1838-1843.

Prasetyo, P. E., Setyadharma, A., \& Kistanti, N. R. (2020d). Social Capital: The main determinant of MSME entrepreneurship competitiveness. International Journal of Scientific \& Technology Research. 9(03), 6627-6637.

Prasetyo, P. E., \& Dzaki, F. Z. (2020e). Institutional performance and new product development value chain for entrepreneurial competitive advantage. Uncertain Supply Chain Management, $8(4), 657-667$.

Prasetyo, P. E. (2019a). The Reliability of Entrepreneurial Productivity as Driver of Economic Growth and Employment. International Journal of Entrepreneurship, 23(4), 1-15.

Prasetyo, P. E. (2019b). Standardization, Comercialization and Productivity on Doormat Creativity Industries Competitiveness. Journal of Economics and Policy, 12(1), 12-26.

Prasetyo, P. E. (2011). Deindustrialization is a Failure Threat of the Triple Track Strategy for Development in Indonesia. Jurnal Ekonomi dan Kebijakan, 4(1), 1-13.

Prasetyo, P. E. (2008). The Role of Micro, Small and Medium Enterprises (UMKM) in Poverty Reduction and Unemployment Policy. Akmenika UPY, 2(1), 1-13. 
Srinivas, K. T. (2013). Role of Micro, Small and Medium Enterprises in Inclusive Growth. International Journal of Engineering and Management Research, 3(4), 57-61.

Syal, M. S. (2015). Role of MSMEs in the Growth of Indian Economy. Global Journal of Commerce \& Management Perspective, 4(5), 40-43.

Tambunan, T. (2019). Recent evidence of the development of micro, small and medium enterprises in Indonesia. Journal of Global Entrepreneurship Research, 9(18), 1-15.

Thanh, S. D., \& Nguyen, P. C. (2019). Dynamics between government spending and economic growth in China: an analysis of productivity growth. Journal of Chinese Economic and Business Studies, 17(2), 189-212.

Uzuner, G., Bekun, F. V., Akadiri, S. S. (2017). Public Expenditures and Economic Growth: Was Wagner Right? Evidence from Turkey. Academic Journal of Economic Studies, 3(2), $36-40$.

Weldeslassie, H. A., Vermaack, C., Kristos, K. Minwuyelet, L., \& Tsegay, M. (2019). Contributions of Micro, Small and Medium Enterprises (MSMEs) to Income Generation, Employment and GDP: Case Study Ethiopia. Journal of Sustainable Development, 12(3), 46-81. 